http://jmscr.igmpublication.org/home/ ISSN (e)-2347-176x ISSN (p) 2455-0450

crossref DOI: https://dx.doi.org/10.18535/jmscr/v7i9.55

Journal Of Medical Science And Clinical Research

\title{
The prevalence of comorbidities among people mainly workers of Bihar state and living with HIV/AIDS in Patna City: An observational trial done in a teaching institute \\ Authors
}

\author{
Dr Sunil Kumar Agrawal*, Dr Surendra Kumar \\ Assistant Professor, Department of T.B. \& Chest, Patna Medical College \& Hospital, Patna, Bihar \\ *Correspondence Author \\ Dr Sunil Kumar Agrawal
}

Assistant Professor, Department of T.B. \& Chest, Patna Medical College and Hospital, Patna, Bihar, India

\begin{abstract}
Aim: The study is aimed to evaluate the prevalence of comorbidities among people living with HIV/AIDS in Patna City.

Method: This is cross sectional observation study among 241 HIV positive patients attending Outpatient Department (OPD) at patna medical college and hospital. Per schedule, structured, self-administered qquestionnaire was used for the data collection.

Result: Respondents age range was 22-75 years where as 31-40 years (38.6\%) was the modal age range. $126(52.3 \%)$ were females, 17 (48.5\%) were government employees and 143 (59.5\%) were married. in present job, 1-45 years were the range of working years. It had been observed that almost all participant had multiple comorbidities and among them $58(24.3 \%)$ respondents were symptomatic. $52(89.7 \%)$ were had fever, $6(8.6 \%)$ were had diabetes mellitus, 26 (44.8\%) were hypertensive, 21 (36.2\%) were had arthritis, 7 (12.1\%) were had tuberculosis and 25 (43.1\%) had persistent diarrhoea. Among the respondents these were the major AIDS defining conditions present. Only significant social factor related to co-morbidities were the age above 50 years. 55 (94.8\%) high pill burden, 48 (82.8\%) had increased side effects, 33 (56.9\%) complaining of cost of medication $79.8 \%$ were hard workplace victimization and these were the major challenges faced by the patients.

Conclusion: It was observed in these study that comorbidities of both non-AIDS defining and AIDS defining were prevalent among our respondents. The respondents who were more likely to develop comorbidities were above 50 years. Assisting management of comorbidities should include in HIV workplace policy.

Keywords: Comorbidities, Prevalence, HIV/AIDS, Patna.
\end{abstract}

\section{Introduction}

Comorbidity of HIV was defined as an acquired immunodeficiency syndrome which associated (AIDS-defining) illness. As the age progressed the major concern is the longer life span for this patients presented with various comorbidity. 1.1 and 1.4were the mean number of HIV-associated comorbidities and general amongst HIV patients [1]. The most common comorbidities associated with HIV includes chronic pulmonary respiratory disease, CV disease including heart failure, hypertension, metabolic disease like diabetes mellitus $^{[2-5]}$.

Mental health of the patients who had infected with HIV is one of the major concern in developing countries and this aspects contributing towards the quality of life of the patients and also these became one of greatest challenge for the 
clinicians. A serious psychological trauma and many different psychological disorder are associated with the infection progress and this have a great impact on patient's life. This situation even interrupts with the further complication and crests burden for medical diagnosis and treatment. It is well known to us that there were limited facilities are available in India to treat mental health related problem which is associated with HIV infection and treatment.

There is an increased need to evaluate the burden of HIV care and its associated diseases in the community, so that commissioning services respond adequately to the changing needs of patients living in the community with HIV and accompanying comorbidity.

\section{Methods}

This is cross sectional observation study among 241 HIV positive patients attending Out Patient Department (OPD) at patna medical college and hospital. Per schedule, structured, selfadministered questionnaire was used for the data collection and personal interview was conducted with the concern patients and others who had attended the OPD with the patients. . Institution based cross-sectional study was conducted. We collected data from 241 adult patients through a face to face interviewing technique using a standardized questionnaire and review of medical records. This interview was conducted in different rooms and kept confidentiality.

Patients writer or verbal concern was taken before initiating the study. The predesigned questionnaire was clearly explained to patients or the attenders who had come with the patients. It has taken care that before initiation of the trial all the participant clearly understood the procedure. Institutional ethical committee approval was taken well before to initiate the trial. All patients who had included in the study were literate and had participated in this trial by their own will.

Variables which have a $p$-value $<0.05$ during bivariable regression were entered into multivariable (binary logistic regression) and finally which have a p-value of $<0.05$ under multivariable (binary logistic regression) were identified as statistically significant association at $95 \%$ of confidence interval.

\section{Results}

Respondents age range was $22-75$ years where as $31-40$ years $(38.6 \%)$ was the modal age range. $126(52.3 \%)$ were females, $17(48.5 \%)$ were government employees and $143(59.5 \%)$ were married. in present job, 1-45 years were the range of working years. (Table 1)

Table-1 Socio-Demographic variables of respondents

\begin{tabular}{|l|c|c|}
\hline Variables & $\begin{array}{c}\text { Frequency } \\
(\mathbf{N}=\mathbf{2 4 1})\end{array}$ & Percent \\
\hline Sex distribution: & & \\
\hline Females & 126 & 52.3 \\
\hline Males & 115 & 47.7 \\
\hline Age range: & & \\
\hline $21-30$ & 51 & 21.2 \\
\hline $31-40$ & 93 & 38.6 \\
\hline $41-50$ & 58 & 24.1 \\
\hline $51-60$ & 33 & 13.7 \\
\hline $61-70$ & 5 & 2.1 \\
\hline 71 and above & 1 & 0.4 \\
\hline Marital status: & & \\
\hline Single & 62 & 25.7 \\
\hline Married & 143 & 59.3 \\
\hline Widowed & 24 & 10 \\
\hline Divorced/separated & 12 & 5 \\
\hline Present/past occupation: & & \\
\hline Government employee & 117 & 48.5 \\
\hline Private employee & 45 & 18.7 \\
\hline Self employed & 79 & 32.8 \\
\hline Total years of working: & & \\
\hline $1-9$ & 139 & 57.7 \\
\hline $10-19$ & 68 & 28.2 \\
\hline $20-29$ & 25 & 10.4 \\
\hline $30-39$ & 6 & 2.5 \\
\hline $40-49$ & 3 & 1.2 \\
\hline
\end{tabular}

It had been observed that almost all participant had multiple comorbidities and among them 58 $(24.3 \%)$ respondents were symptomatic. 52 $(89.7 \%)$ were had fever, 6 (8.6\%) were had diabetes mellitus, 26 (44.8\%) were hypertensive, $21(36.2 \%)$ were had arthritis, 7 (12.1\%) were had tuberculosis and 25 (43.1\%) had persistent diarrhoea. (Table 2) 
Table-2: Prevalence of co-morbid conditions and AIDS-related symptoms among PLWHA at time of study

\begin{tabular}{|l|c|c|}
\hline Variable & Frequency & Percent \\
\hline $\begin{array}{l}\text { Presence of co-morbid conditions or } \\
\text { AIDS-related symptoms: }\end{array}$ & $\mathrm{N}=241$ & \\
\hline Yes & 59 & 24.5 \\
\hline No & 182 & 75.5 \\
\hline Types of co-morbid conditions: & $\mathrm{N}=58$ & \\
\hline $\begin{array}{l}\text { AIDS related comorbidities or } \\
\text { AIDS-related symptoms: }\end{array}$ & & \\
\hline Persistent febrile illness & 52 & 89.7 \\
\hline Generalized muscle pains & 33 & 56.9 \\
\hline Persistent diarrhea & 25 & 43.1 \\
\hline Generalized rash & 19 & 32.8 \\
\hline Extreme fatigue & 15 & 25.9 \\
\hline Anorexia & 13 & 22.4 \\
\hline Insomnia & 12 & 20.7 \\
\hline Tuberculosis & 7 & 12.1 \\
\hline Cancer & 2 & 3.4 \\
\hline Epilepsy & 1 & 1.7 \\
\hline None AIDS Related Comorbidities: & & \\
\hline Hypertension & 26 & 44.8 \\
\hline Arthritis & 21 & 36.2 \\
\hline Typhoid fever & 6 & 8.6 \\
\hline Diabetes & 6 & 8.6 \\
\hline Hepatitis & 3 & 5.2 \\
\hline Peptic ulcer disease & 2 & 3.4 \\
\hline Renal problem & 2 & 3.4 \\
\hline
\end{tabular}

Among the respondents these were the major AIDS defining conditions present. only significant social factor related to co-morbidities were the age above 50 years. 55 (94.8\%) high pill burden, 48 $(82.8 \%)$ had increased side effects, $33(56.9 \%)$ complaining of cost of medication $79.8 \%$ were had workplace victimisation and these were the major challenges faced by the patients. (Table 3 )

Table-3: Period of diagnosing the co-morbid condition and associated challenges in its management

\begin{tabular}{|l|c|c|}
\hline Variables & $\begin{array}{c}\text { Frequency } \\
\mathbf{N = 5 8}\end{array}$ & Percent \\
\hline Period of diagnosing the co-morbidity: & & \\
\hline Before developing HIV/AIDS & 24 & 41.4 \\
\hline After developing HIV/AIDS & 30 & 51.7 \\
\hline I do not know & 4 & 6.9 \\
\hline $\begin{array}{l}\text { Challenges in managing the co- } \\
\text { morbidities: }\end{array}$ & 55 & 94.8 \\
\hline Too many drugs to take & 48 & 82.8 \\
\hline More side effects & 33 & 56.9 \\
\hline Increased cost of medication & 13 & 22.4 \\
\hline $\begin{array}{l}\text { Difficulties with controlling the co- } \\
\text { morbid condition }\end{array}$ & 3 & 5.2 \\
\hline Nothing & & \\
\hline
\end{tabular}

\section{Discussion}

Like general healthcare facility urban and rural both needed a specilieased treatment care center which provides diagnosis, effective screening, treatment and prevention of the disease. a high prevalence of chronic pain, an increasing prevalence of other chronic diseases oral health needs and co-morbid presence of mental health and substance abuse disorders are the major and common challenges to the healthcare professional who were dealing with PLWHA. It had been observed that this condition further develops other chronic medical co-morbidities, including $\mathrm{CV}$ disease like heart faifure, hrpertention, diabetes mellitus, cognitive impairment, osteoporosis and cancer as the age progressed which further complicate the situation ${ }^{[6]}$. Several studies had confirmed that lifestyle diseases and cardiovascular diseases are the two most common complication which is associated with the disease progression $^{[7]}$. Our study has correlated with some older studies which address the issue that even patients who lived in old age homes where the situation was more worsening and it further detoriate when co prescription for addressing the comorbid condition required ${ }^{[8,9]}$.

Among older persons number of comorbidities as chronic medical conditions are known to be commoner and which are in rise. In our study we had observed that a preponderance of females like many previous study, but the difference did not appear significant ${ }^{[10-12]}$. This observational study once again confirm that prevalence of various comorbidities among HIV patients is need to be taken as priority and HIV management with management of common medical comorbidities.

People who generally suffered from HIV/AIDS were also frequently encounter with mental depression or other major depressive disorder which is twofold more frequent compare to general population ${ }^{[13]}$. This common incidence among HIV infected people are common mainly because of the various complications of antiretroviral therapy (ART) ${ }^{[14-16]}$. Thus clinicians should be more causious and attentive regarding 
screening, diagnosis and management of mental disorder associated with PLWHA ${ }^{[17]}$.

\section{Conclusion}

It was observed in these study that comorbiditiesof both non-AIDS defining and AIDS defining were prevalent among our respondents. The respondents who were more likely to develop comorbidities were above 50 years. Assisting management of comorbidities should include in HIV workplace policy.

\section{Reference}

1. Health Protection Agency. HIV-diagnosed Persons Seen for Care - Survey of Prevalent HIV Infections Diagnosed (SOPHID) North West London. HPA: London, nd.

www.hpa.org.uk/webc/HPAwebFile/HPA web_C/ $1221482345789 \quad$ (accessed 23/06/2014).

2. Kilbourne AM, Justice AC, Rabeneck L, Rodriguez- Barradas $M$ andWeissman S.VACS 3 Project Team. General medical and psychiatric comorbidity among HIVinfected veterans in the post-HAART era. Journal of Clinical Epidemiology 2001;54 (Suppl 1):S22-8.

3. Turner J, Bansi L, Gilson R et al. The prevalence of hepatitis $\mathrm{C}$ virus (HCV) infection in HIV-positive indi- viduals in the UK - trends in HCV testing and the impact of HCV on HIV treatment outcomes. Journal Viral Hepatitis 2010;17:569-77.

4. Sudano I, Spieker LE, Noll G, Corti R, Weber R andLuscher TF. Cardiovascular disease in HIV infection. American Heart Journal 2006;151:1147-55.

5. Crothers K, Butt AA, Gibert CL et al. Increased COPD among HIV-positive compared to HIV-negative vet- erans. Chest 2006;130:1326-33.

6. Chu, C., Umanski, G., Blank, A., Meissner, P., Grossberg, R., \&Selwyn, P.
A. (2011). Comorbidity-related treatment outcomes among HIV-infected adults in the Bronx, New York. Journal of Urban Health, 88(3), 507-516.

7. Weiss JJ, Osorio G, Ryan E, Marcus SM, Fishbein DA. Prevalence and patient awareness of medical comorbidities in an urban AIDS clinic. AIDS Patient Care STDs. 2010;24(1):39-48.

8. Lyons M., Pitts M., Grierson J., Thorpe R. and Power J., Ageing with HIV: health and psychosocial well-being of older gay men, AIDS Care, 22(10), 1236-44 (2010)

9. Negin J., Martiniuk A., Cumming R.G., Naidoo N., Phaswana-Mafuya N., Madurai L., Williams S. and Kowal P., Prevalence of HIV and chronic comorbidities among older adults, AIDS, 26, S55-S63 (2012)

10. Laah J.G. and Ayiwulu E., SocioDemographic characteristics of patients diagnosed with HIV/AIDS in NasarawaEggon, Asian J Med Sci, 2(3), 114-120 (2010)

11. Anyebe E.A., Hellandendu J.M. and Gyong J.E., Socio- demographic profile of people living with HIV/AIDS (PLWHA) in Idoma land, Benue Sttate, North central Nigeria: Implications for HIV/AIDS control, Intel J Soc and Anthrop, 5(5), 153-162 (2013)

12. Iliyasu Z., Arotiba J.T. and Babashan M., Socio- demographic characteristics and risk factors among HIV/AIDS patients in Kano, Northern Nigeria, Niger J Med, 13(3), 267-271 (2004)

13. Kolappa K, Henderson DC, Kishore SP. No physical health without mental health: lessons unlearned? Bull World Health Org 2013;91:3-3a.

14. Freeman M, Patel V, Collins PY, Bertolote J. Integrating mental health in global initiatives for HIV/AIDS. Br J Psychiatry 2005;187:1-3.

15. Thom RGM. HAART and Mind: Common Mental Disorders in People Living with 
HIV/AIDS. The Access Series. South Africa: Reach Publishers, 2012.

16. Blank MB, Eisenberg MM. Tailored treatment for HIV + persons with mental illness: The intervention cascade. J Acquir Immune Deficiency Syndr 2013;63:S44S48.

17. Joska JA, Westgarth-Taylor J, Myer L, et al. Characterization of HIV associated neurocognitive disorders among individuals starting antiretroviral therapy in South Africa. AIDS Behav 2011;15(6):1197-1203. 